\title{
Therapeutic Potential of Bone Marrow Derived Mesenchymal Stem Cells in Modulating Astroglyosis of Surgical Induced Experimental Spinal Cord Injury
}

\author{
Moataz A. Elawady¹, Mohammed M. Elmaghrabi', Nesrine Ebrahim², Mona A. Elawady ${ }^{3}$, \\ Dina Sabry ${ }^{*}$, Ashraf Shamaa5, Alyaa Ragaei6 \\ ${ }^{1}$ Neurosurgery Department, Faculty of Medicine, Banha University, Banha, Egypt \\ ${ }^{2}$ General Histology Department, Faculty of Medicine, Banha University, Banha, Egypt \\ ${ }^{3}$ Community Medicine Department, Faculty of Medicine, Banha University, Banha, Egypt \\ ${ }^{4}$ Medical Biochemistry Department, Faculty of Medicine, Cairo University, Giza, Egypt \\ ${ }^{5}$ Surgical and Radiology Department, Faculty of Veterinary Medicine, Cairo University, Giza, Egypt \\ ${ }^{6}$ General Histology Department, Faculty of Oral and Dental Medicine, Future University, Cairo, Egypt \\ Email: "dinasabry@kasralainy.edu.eg
}

Received 4 January 2016; accepted 20 June 2016; published 23 June 2016

Copyright (C) 2016 by authors and Scientific Research Publishing Inc.

This work is licensed under the Creative Commons Attribution International License (CC BY).

http://creativecommons.org/licenses/by/4.0/

(c) (i) Open Access

\section{Abstract}

Background: Spinal cord injury (SCI) unsuccessful regeneration was due to glial scar development. It was a major obstacle to axonal restoration. Safe therapeutic intervention by the use of bone marrow derived stem cells (BMMSCs) transplantation applied in the present study could reduce spinal disability. Material and methods: Forty male albino rats were divided into four groups: GI: negative control ( $n=10$ rats); GII: positive control after SCI ( $n=10$ rats); GIII: SCI + BM - MSCs intravenous injected and GIV: SCI + BM - MSCs intra lesion injected ( $\mathrm{n}=10$ rats in each group). The samples were taken from spinal cord tissues around the region of injury and were subjected to histological, immunohistochemical assessment. RNA extraction and real time PCR for detection of nerve regeneration and astrocyte response to the injury were also performed. Results: Clinical improvement occurred by the enhancement in the Basso, Beattie and Bresnahan (BBB) score after SCI. Histological examinations showed positive regenerative responses in GIV compared to GIII. Conclusion: BM-MSCs transplantation has a promising role in enhancing the microenvironment for nerve regeneration through stumbling the glial scaring formation and inflammatory response after chronic spinal cord injury especially by using intra-lesion route injection. 


\section{Keywords}

\section{Spinal Cord Injury—Bone Marrow Mesenchymal Stem Cells, Rats and Glial Tissue}

\section{Introduction}

In the last couple of years, spinal cord injury (SCI) was the most devastating ailment afflicting males. A complete injury results in: permanent paralysis with complete loss of sensation in the affected limbs and trunk, as well as loss of bowel, bladder, and sexual functions [1].

SCI does not only cause disabilities. It also has a deep impact on the social and economic prospects of the individual and the whole community. The high costs of treatment and prolonged hospitalization are an economic load on individual, the family and the society [2].

The main cause for SCI especially at a young age was found to be accidents. As of now, there is no established therapeutic intervention capable of restoring significant neurological functions after SCI [3].

Recent advances in stem cell research have bestowed great hope amongst researchers for the development of new treatments for many serious diseases. Finding out the potential of these cells demands significant scientific and medical evidence to derive beneficial ways which may then be offered as a clinical alternative to other existing present therapies [4].

SCI is followed by secondary events including a strong inflammatory reaction which results in secondary tissue destruction and additional loss of the tissue function [5]. The unembellished lesions become dominated by the deposition of scar tissue composed of connective tissue and fluid-filled cysts, surrounded by dense, astroglial scars [6].

Several studies on experimental animals exhibit how this scar represents a physical and molecular barrier, which isolates the lesion site from adjacent, healthy tissues. Meanwhile, it is also considered a center for the lack of axonal regrowth after injury [7].

In our study, we aimed at focusing on the role of BM-MSCs and some growth factors in increasing or decreasing SCI.

Under normal physiological conditions, there is a dynamic balance between synthesis and degradation of tissue using the help of Matrix Metalloproteinases (MMPs) — a family of proteolytic enzymes — which is largely controlled by chemokines and cytokines secreted by inflammatory cells such as: Transforming Growth Factor- $\beta$ (TGF- $\beta$ ) [8].

The role of TGF- $\beta$ in scar formation post-spinal cord injury explains why we use it as a parameter to observe the healing effect pronounced after BM-MSCs injection [9] [10].

In previous experiments of SCI, TGF- $\beta$ isoforms were shown not only to be involved in the early inflammatory response, but also to play an essential role in the formation of the scar at the lesion site. However, the extent to which experimental SCI induced changes of TGF- $\beta$ expression, reflecting the events taking place following human SCI; remains unknown. Thus, the present investigation was undertaken to determine the pattern of TGF- $\beta$ expression in samples, taken from animals of different groups following severe SCI and treatment [11]-[13].

It was postulated that the functional recovery after SCI is not simply a significance of the mechanical destruction of tissue, but also ascribed to the appearance of complex secondary events leading to the regenerative failure of injured axons and formation of a glial scar.

The glial scar consists mainly of reactive astrocytes that arrest axon regeneration by secretion of chondroitin sulfate proteoglycans (CSPGs) which chemically arrest the regrowth [14].

The glial scar formation took place due to astrocyte migration in the area of the lesion [15] [16]. The proliferative action of astrocytes depends on: actin cytoskeleton mediated by the small GTPases [17] [18], integrity of the intermediate filament including vimentin and glial fibrillary acidic protein (GFAP), cell adhesion [19] [20], and water invasion through the cells' plasma membrane [21].

Matrix metalloproteinases (MMPs) is a family of zinc-dependent endopeptidases that can destroy a variety of protein constituents in the extracellular matrix (ECM) and thus remodel per cellular microenvironment for cell translocation [22]. MMPs modulate numerous pathological and tissue-repair processes in the nervous system; particularly those that require cell migration [23].

In the injured spinal cord, it is likely that MMPs may exert both constructive and disadvantageous effects, depending upon which members of the family are involved and where they are actively expressed [24] [25].

Many investigators observed that MMP-2 and MMP-9 are expressed in reactive astrocytes after SCI, raising 
the possibility that these MMPs may participate in the formation of the glial scar. Recent studies have shown that astrocyte migration is modulated by MMPs [26] [27].

The multipotent properties of MSCs and their remarkable malleability -to the extent that they can differentiate into lineage other than the tissue origin-sorted them into a suitable choice for studying their therapeutic effects in different injuries [28].

\section{Materials and Methods}

Forty male Albino rats were of 6 weeks old, weighing between 200 and 250 g. Rats were bred and maintained in an air-conditioned animal house with specific pathogen-free conditions. All experimental animals have ethical approval from the institutional animal care committee. They were subjected to a normal cycle and allowed to balance diet and water. All experimental protocols followed the guidelines of the Animal Committee of the Faculty of Medicine of Cairo University.

\subsection{Experimental Design}

Rats were divided into the following groups:

1) G I (Control group): 10 rats not exposed to SCI and served as -ve control.

2) GII (Spinal cord Injured group): 10 rats have surgical induced SCI and served as +ve control.

3) GIII (Spinal cord injury/BM-MSCs Intravenous group): 10 rats have surgical induced SCI. The rats were infused with $10^{7} \mathrm{MScs} / \mathrm{rat}$ intravenously (through tail vein) and scarified after 6 weeks.

4) GIV (Spinal cord injured/BM-MSCs Intra-lesion group): 10 rats have surgical induced SCI. The rats were infused with $10^{7} \mathrm{MScs} /$ rat intra lesion and scarified after 6 weeks.

All rats were sacrificed and spinal cord tissue was harvested for histopathological, immunohistochemical examination and real time PCR analysis.

\subsection{Induction of Spinal Cord Injury}

We performed surgical SCI induction according to Erbayraktar, Gokmen and Yilmaz [29]. In brief, Aseptic T9-T10 laminectomy under anesthesia (pentobarbital sodium; dose 50 - 80 mg/kg IP; Hospira, Lake Forest, IL) was performed. Spinal cord contusion was induced using a weight-drop apparatus, where a guided $10 \mathrm{~g}$ rod was dropped 12.5 or $25 \mathrm{~mm}$ onto the exposed dura mater, representing moderate or severe SCI, respectively.

\subsection{Isolation and Culture of BM-MSCs}

Bone marrow cells were flushed from tibia and fibula of rat bones with phosphate-buffered saline (PBS) containing 2 mM EDTA. Over $15 \mathrm{ml}$ Ficoll-Paque (Gibco-Invitrogen, Grand Island, NY), $35 \mathrm{ml}$ of the diluted sample was carefully layered, centrifuged for 35 minutes at $400 \mathrm{xg}$ rpm and the upper layer was aspirated leaving undisturbed mononuclear cell (MNC) layer at the interphase. This MNC layer was aspirated, washed twice in PBS containing $2 \mathrm{mM}$ EDTA and centrifuged for 10 minutes at $200 \mathrm{xg} \mathrm{rpm}$ at $10^{\circ} \mathrm{C}$. The cell pellet was re-suspended in a final volume of $300 \mu \mathrm{l}$ of buffer. Isolated MSCs were cultured on $25 \mathrm{ml}$ culture flasks in minimal essential medium (MEM) supplemented with 15\% fetal bovine serum (FBS) and incubated for 2 hours at $37^{\circ} \mathrm{C}$ and $5 \% \mathrm{CO}_{2}$. Adherent MSCs were cultured in MEM supplemented with 30\% FBS, $0.5 \%$ penicillin, streptomycin and at $37^{\circ} \mathrm{C}$ in $5 \% \mathrm{CO}_{2}$ in air [12]. Cultured MSCs was confirmed by morphology and Florescent Analysis Cell Sorting (FACS) by detection of CD29 ${ }^{+}$and $\mathrm{CD} 44^{+}$specific to MSCs.

\subsection{Labeling Stem Cells with GFP}

At $4^{\text {th }}$ passage, MSCs were harvested and labeled with GFP (amaxa GmbH, amaxa Inc. Europe/World USA Scientific Support). MSCs were nucleofected using the MSC Nucleofector Kit and a plasmid encoding the fluorescent protein GFP. Cells were centrifuged, washed twice in serum free medium, pelleted and suspended in nucleofector solutions. A final concentration of $(4-5) \times 10^{5}$ cells/100 $\mu$ l nucleofector solutions was applied. The sample was placed in cuvette of elactroporation transfection instrument at program U-23 (for high transfection efficiency) or C-17 (for high cell survival). 24 hours post-nucleofection cells were analyzed by light and fluorescence microscopy. Transfection efficiencies of around $80 \%$ can be reached with GFP. Labeled cells were injected intravenously in rat with surgical induced SCI. After 6 weeks, spinal cord tissue was examined with a 
fluorescence microscope (Leica, Germany) to detect and trace the cells stained with GFP.

\subsection{Histopathological Examination}

Spinal tissues were collected and divided into two sections. The first section was assessed for tracing of injected labeled cells with GFP. The second section was washed with PBS and fixed overnight in $40 \mathrm{~g} / \mathrm{L}$ paraformaldehyde at $4^{\circ} \mathrm{C}$. Serials $(\mu \mathrm{m}$ sections of the dissected spinal cord tissues were stained with hematoxylin and eosin (H\&E) [30].

\subsection{Immunohistochemistry}

Immunohistochemical staining was performed on 5- $\mu$ m, formalin-fixed, paraffin-embedded sections using the glialfibillary acidic protein (GFAP) antibodies and anti myline basic protein (MBP) antibody at 1:50 dilution (DAKO, Carpinteria, CA). Antigen retrieval was performed in all cases by steam heating the slides in a 1-mmol/L solution of EDTA ( $\mathrm{pH}$ 8.0) for 30 minutes. After blocking of endogenous biotin, staining was performed using an automated immunostainer (DAKO) followed by detection by using a streptavidin-biotin detection system (DAKO). Positive and negative control sections were used for each assay [31].

\subsection{Computer Assisted Digital Image Analysis (Digital Morphometric Study)}

Slides were photographed using Olympus digital camera installed on microscope with $1 / 2 \mathrm{X}$ photo adaptor, using $40 \mathrm{X}$ objective. The result images were analyzed by using (Russia) software with a specific built-in routine for stain quantification. 5 slides from each case were prepared, 5 random fields from each slides were analyzed. Integrated density of the immunostain was quantified and exported to an excel sheet for statistical analysis.

\subsection{RNA Extraction}

Tissue of all studied groups was homogenized and total RNA was isolated with RNAeasy Mini Kit (Qiagen) and further analyzed for quantity and quality with Beckman dual spectrophotometer (USA).

\subsection{Real Time PCR (qRT-PCR)}

For quantitative expression of TGF- $\beta$, MMP-2 and MMP-9 genes; the following procedure were assessed. 200 ng of the total RNA from each sample were used for cDNA synthesis by reverse transcription using High capacity cDNA Reverse Transcriptase kit (Applied Biosystem, USA). The cDNA was subsequently amplified with the Syber Green I PCR Master Kit (Fermentas) in a 48-well plate using the Step One instrument (Applied Biosystem, USA) as follows: 10 minutes at $95^{\circ} \mathrm{C}$ for enzyme activation followed by 40 cycles of 15 seconds at $95^{\circ} \mathrm{C}$, 20 seconds at $55^{\circ} \mathrm{C}$ and 30 second at $72^{\circ} \mathrm{C}$ for the amplification step. Changes in the expression of each target gene were normalized relative to the mean critical threshold (CT) values of GAPDH housekeeping gene by the $\Delta \Delta \mathrm{Ct}$ method. We used $1 \mu \mathrm{M}$ of both primers specific for each target gene. Primers sequence and annealing temperature specific for each gene demonstrated in Table 1.

\subsection{Behavioral Assessment}

The functional status of the hindlimbs was assessed 6 weeks after SCI, using the Basso, Beattie and Bresnahan

Table 1. Primers sequence and annealing temperature specific for each gene.

\begin{tabular}{|c|c|c|}
\hline Target gene & Primer sequence: 5’-3’ & Gene bank accession number \\
\hline TGF- $\beta$ & $\begin{array}{c}\text { Forward: TGCGCCTGCAGAGATTCAAG } \\
\text { Reverse: AGGTAACGCCAGGAATTGTTGCTA }\end{array}$ & NM021578.2 \\
\hline MMP-2 & $\begin{array}{l}\text { Forward: CTATTCTGTCAGCACTTTGG } \\
\text { Reverse: CAGACTTTGGTTCTCCAACTT }\end{array}$ & NM031054.2 \\
\hline MMP-9 & $\begin{array}{l}\text { Forward: AAATGTGGGTGTACACAGGC } \\
\text { Reverse: TTCACCCGGTTGTGGAAACT }\end{array}$ & NM031055.1 \\
\hline GAPDH & $\begin{array}{l}\text { Forward: CACCCTGTTGCTGTAGCCATATTC } \\
\text { Reverse :GACATCAAGAAGGTGGTGAAGCAG }\end{array}$ & NG028301.2 \\
\hline
\end{tabular}


(BBB) locomotor rating scale [32].

\subsection{Statistical Analysis}

Measurement data are expressed as the mean \pm SD. Statistical analyses were performed with SPSS 12.0 software (SPSS, Chicago, IL, USA). For cell viability assays, analysis of variance (ANOVA) was applied to identify significant differences. BBB locomotor rating scores and cell counts at different time points were carried out using repeated measures analysis of variance. $\mathrm{p}<0.05$ was considered statistically significant.

\section{Results}

\subsection{Morphological, Phenotype Characteristics and GFP-Labeling Identification of Expanded Undifferentiated (BMSCs)}

Under an inverted microscope (Leica, Germany).Undifferentiated (BMSCs) were typical of adherent spindle and fibrocyte-like at one week culture and reached $80 \%$ - 90\% confluence at 2 weeks culture (Figure 1(a) and Figure 1(b) respectively). After plastic adherence selection, BMSCs were culture over four passages. Flow cytometric analysis of the MSCs at the 4th passage showed that these cells were positive for CD90 (96.2\%) and CD 73 (98.7\%) and negative of hematopoietic/ endothelial markers CD45 (0\%) (Figure 1(c)). These results indicated that relatively purified (BM-MSCs) were isolated. Before cells injecting, GFP-labelled BM-MSCs were analyzed and confirmed for their green auto fluorescence for in vivo cells tracing (Figure 2(a)).

\subsection{BMSCs Homing and Florescence Assessment}

Frozen florescence microscopy of the section of the cell treated spinal cord tissue of all groups indicated that the GFP-transduced injected cells were assimilated within spinal cord tissue (Figure 2(b)).

\subsection{Behavior Assessment}

At $5^{\text {th }}$ week after injection of mesenchymal stem cells, there are improvements in locomotor function $(\mathrm{p}>0.01)$
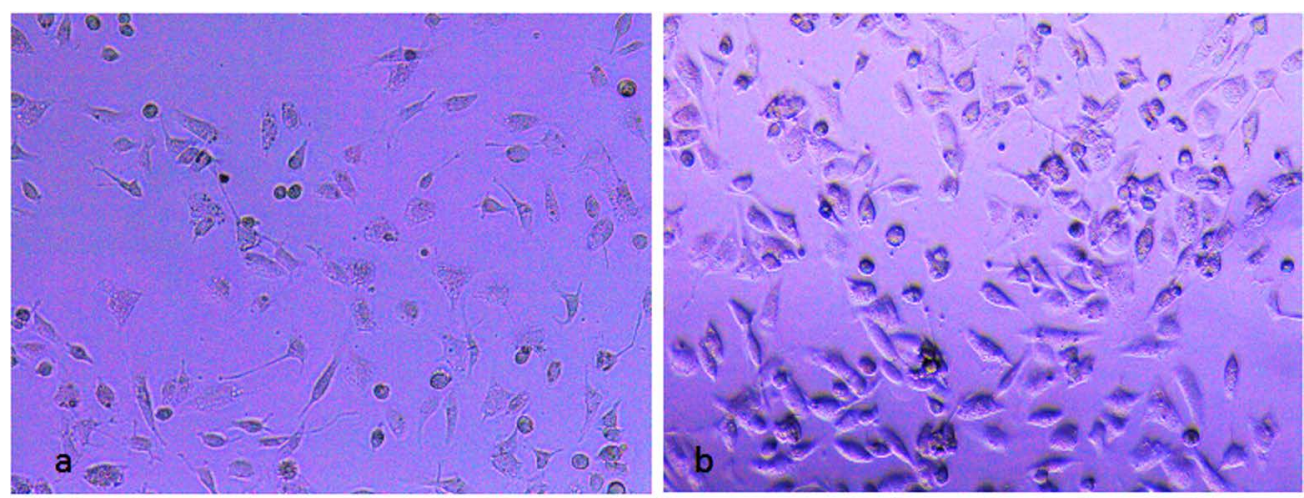

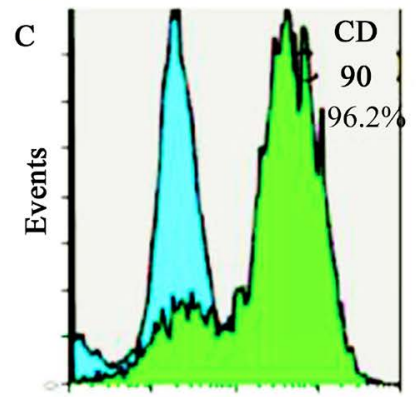

FI.1I,OG

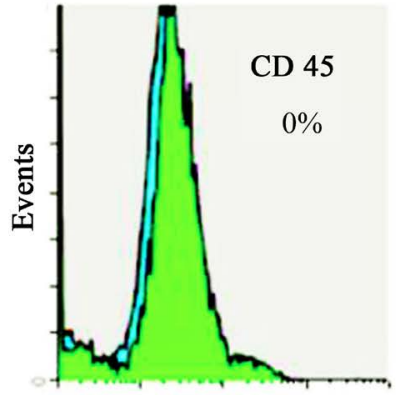

FI.1I.OG

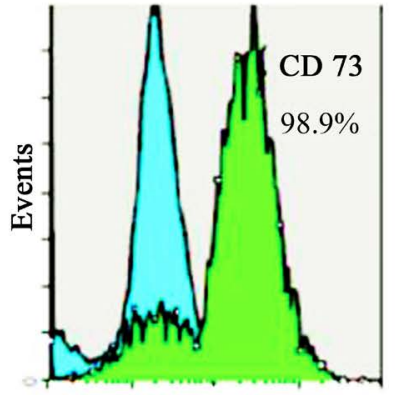

FI.1LOG

Figure 1. (a) BMSCS at one week of culture (30\% - 40\% confluent), (b) BMSCs at two weeks of culture (80\% - $90 \%$ confluent), (c) it shows CD markers expressed for mesenchymal stem cells. 

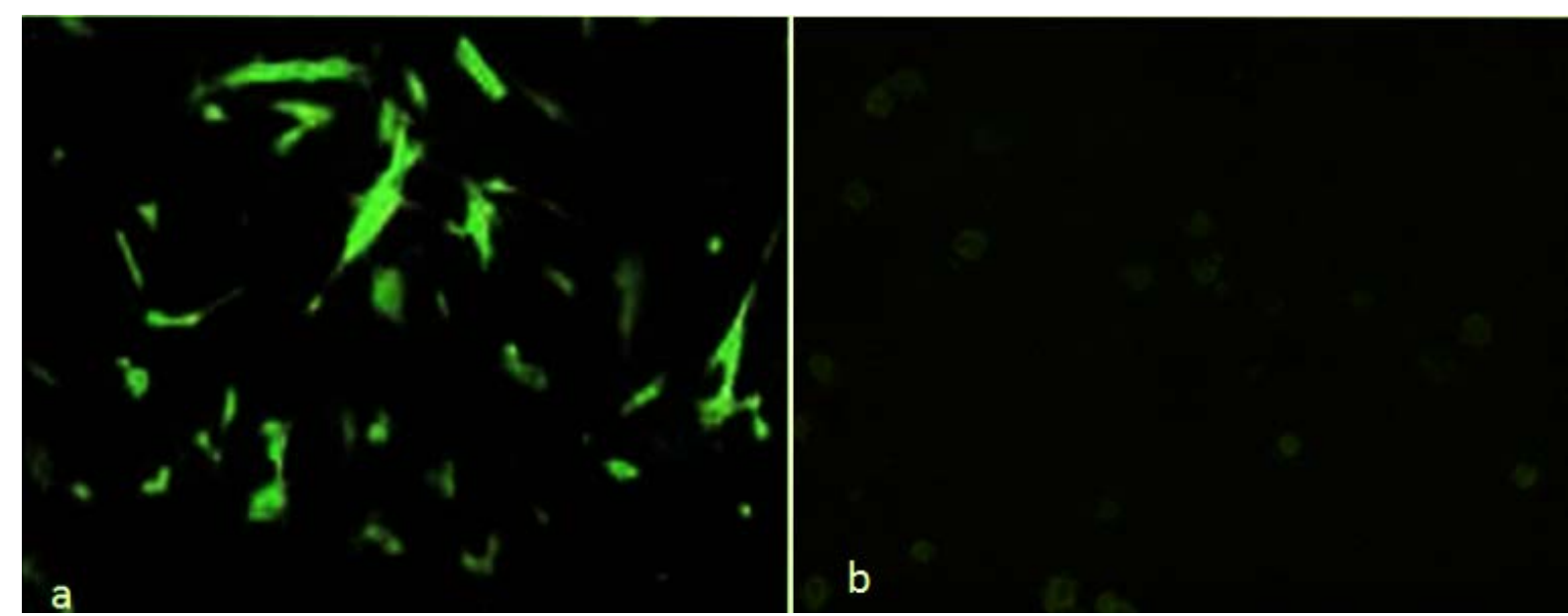

Figure 2. (a) Labeling of BMSCs with GFP fluorescent dye (in vitro), (b) homing of the injected labeled BMSCs by detecting GFP fluorescent dye in the rat spinal cord tissue (in vivo).

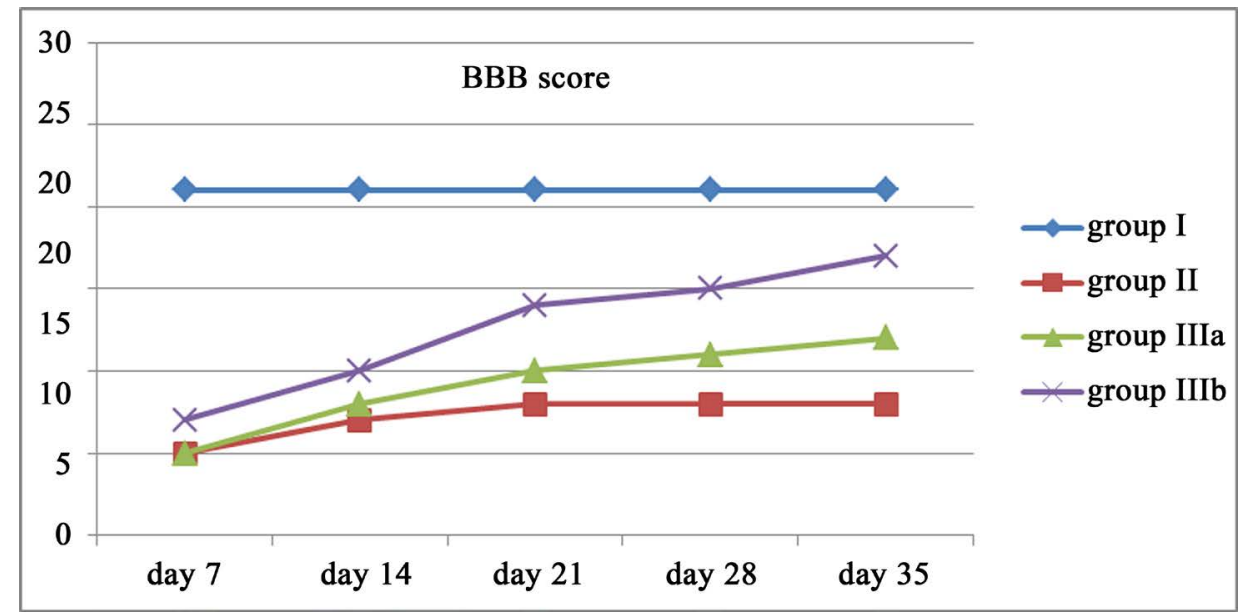

Figure 3. Showed histogram for the assessed motor and sensory functions of rats in all studied groups.

such that GIII and GIV showed a significant increase in BBB score compared with control group p $>0.01$.

This trend indicates that mesenchymal stem cells injection is necessary for locomotor function recovery. At the $1^{\text {st }}$ week after injection GIV showed significant increase in BBB score compared with GI but at $1^{\text {st }}$ week after injection intravenous GIII showed significant decrease in BBB score compared with GI $p>0.01$ which was gradually increased showing increased locomotor function at the fifth week post stem cells injection. Motor and sensory functions were demonstrated at Figure 3.

\section{Histopathological Results}

GI (Control group): Spinal cord sections showed normal architecture where the grey matter surrounded by white matter. The ventral horn with number of processes extends into the white mater. Large multipolar cells that are relatively large compared to the nerve fibers which surround these cells. The surrounding nerve fibers are neuroglial cells, although the cytoplasm of these cells is not visible (Figure 4(a), Figure 4(b)).

Meanwhile Untreated GII: spinal cord sections 36 days post injury showed hemorrhagic emphasis in the grey and white matters with complete destruction of the tissue, this was represented in neuron dissolution giving liquefied appearance in grey matter (Figure 5(a)). Sections of this injured group showed as well eosinophilic (degenerating) neurons and pyknotic nuclei. Swollen cells and many vacuoles were demonstrated. Some dark shrunken neurons were also detected (Figure 5(b)). There was deceptive cellular destruction and necrosis as compared to all other groups (Figure 5(c), Figure 5(d)). 


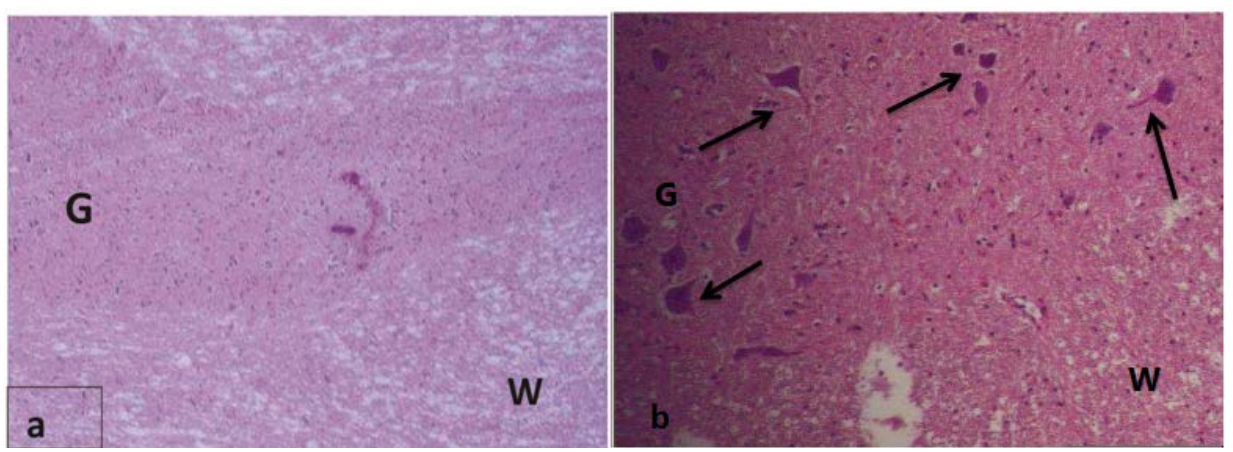

Figure 4. (a) Photomicrograph GI: showing normal view of the grey matter $(G)$ of the spinal cord which is clearly surrounded by white matter (W). The ventral horn has a number of processes which extend into the white mater (H\&E $\times 100)$. (b) Photomicrograph GI: normal spinal cord tissue displaying number of multipolar cells (arrow) that are relatively large compared to the nerve fibers which surround these cells $(H \& E \times 200)$.
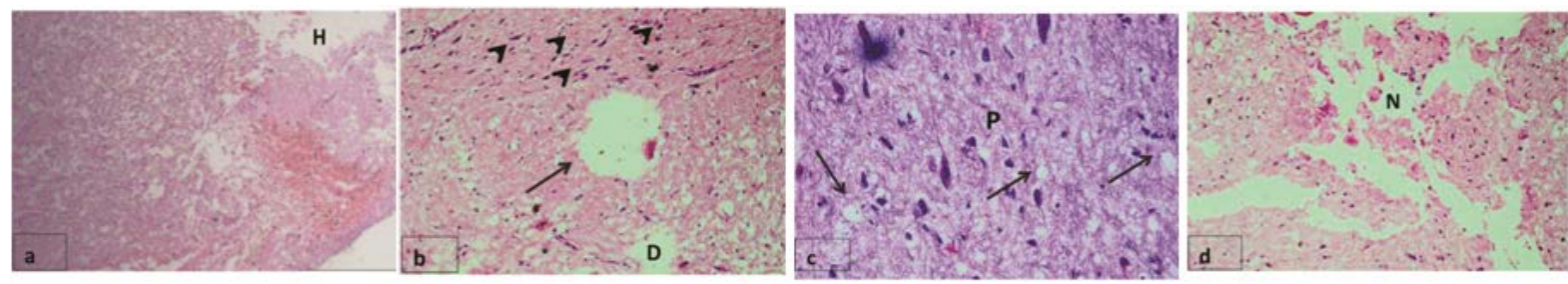

Figure 5. (a) photomicrograph of spinal cord tissue section of GII (untreated group): showing hemorrhagic focus (H) in the grey and white matters $(\mathrm{H} \& \mathrm{E} \times 100)$. (b) photomicrograph of spinal cord tissue section GII :showing neuron dissolution giving liquefied appearance in grey matter (arrow), degenerated areas and well eosinophilic degenerating neuron (arrow heads) $(H \& E \times 100)$. (c) Photomicrograph of spinal cord tissue section GII: showing swollen cells and many vacuoles (arrow) some dark irregular shrunken neurons with pyknotic nuclei $(P)$ were demonstrated $(H \& E \times 200)$. (d) Photomicrograph of spinal cord tissue section GII: showing apparent cellular destruction and necrosis $(\mathrm{N})$ as compared to all other groups $(\mathrm{H} \& \mathrm{E} \times 100)$.

Group III in which animals were intravenously treated with BM-MSCs spinal cord sections showed, apparently more glia cells and less dark neurons as compared to both normal control and untreated groups (Figure 6(a)). In addition, some areas showed inflammatory infiltrates, pyknotic cells surrounded by diffused glial cells with the presence of some vacuoles (Figure 6(b)).

Group IV animals were treated intra lesion with BM-MSCs. spinal cord sections showed normal structure of spinal cord tissue: the neurons are well observed, the outer limits of the grey \& white matters are marked with no cystic spaces (Figure 7(a), Figure 7(b)). However, a small hemorrhage aggregation was still observed in some sections as well as slight gathering of gliocytes were still denoted (Figure 7(c)).

\section{Quantitative Genes Expression}

Regarding gene expression, TGF- $\beta$, gene was highly expressed in GII and expression was significantly decreased after stem cells administration. Least expression was in GI. Nevertheless, there was significant difference between GIII and GIV where GIII showed higher expression than GIV. As regard to gene expressions of MMP-2 and MMP-9; they were highly expressed in spinal cord tissues in the GII, while significant decrease in their expression in both GIII \&GIV compared to GII. MMP-9 and MMP-2 genes in GIV were significantly highly expressed compared to control group GI (Table 2).

\section{Immunohistochemistry Results}

Anti-GFAP stained spinal cord sections: spinal cord sections of GI exposed brown immunostaining in the cytoplasm and processes of astrocytes in all regions in white and grey matter. The immunoreactive cells were detected mainly in a regular form in both regions (Figure 8(a), Figure 8(b)). GII showed highly significant immunoreactivity as compared to GI and all other groups; the immunoreactive astrocytes were detected mainly in all spinal tissues closely related to site of the lesion The dense packing of intensely GFAP-positive astroglial 
processes between the spaces made it extremely difficult to comment on changes in astrocytic cell body density (Figure 9(a), Figure 9(b)). Comparing both GIII intravenous and GIV intra lesion treated groups to the untreated group, Anti-GFAP stained spinal cord sections showed moderate reactivity which was restricted to the place of lesion as going further away from the lesion site, no significant astrocytic reaction could be detected. There was no indication of increased GFAP immunoreactivity, and the astrocytic processes and cell bodies appeared normal in both grey matter and white matter tracts (Figure 10(a), Figure 10(b)). Still GIV showed better results rather than GIII. Table 3 showed the mean area percent of GFAP and mylien basic protein immunopositive cells in control and all experimental groups.
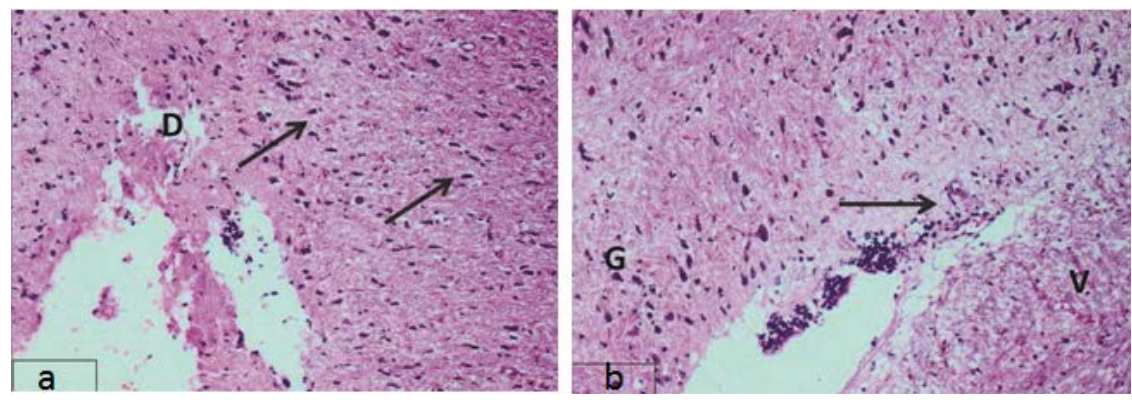

Figure 6. (a) photomicrograph of spinal cord tissue section of group III (intravenously treated with BMSCs) showing apparently more glia cells and less dark neurons (arrow) and degenerated areas (D) (H\&E $\times 100)$. (b) photomicrograph of spinal cord tissue section of group III intravenously treated with BMSCs showing some areas inflammatory infiltrates (arrow), pyknotic cells surrounded by diffused glial cells $(G)$ \&with mild vacuolation (V) (H\&E ×100).
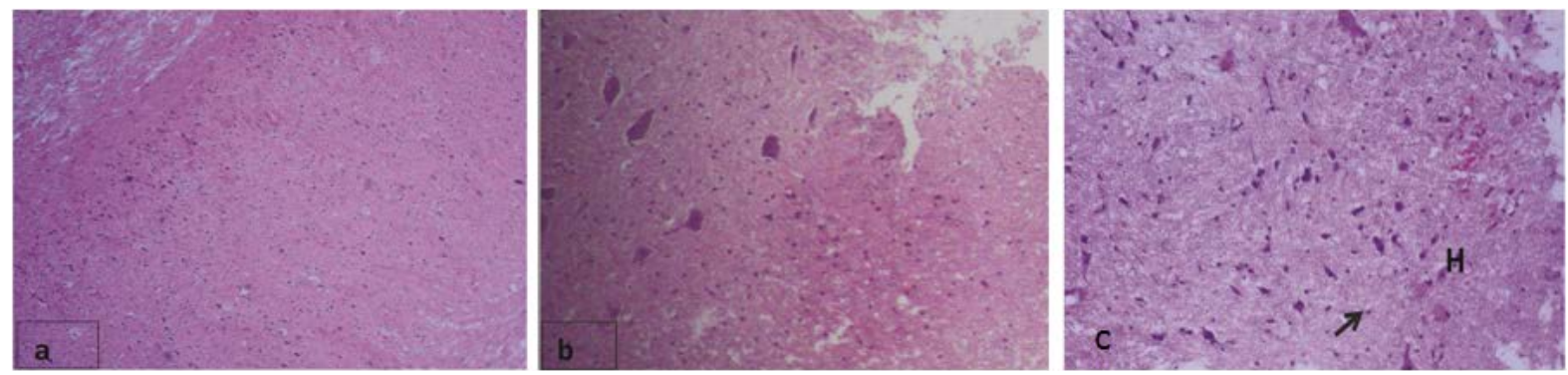

Figure 7. ((a), (b)) Photomicrograph of GIV: (intra lesion injection BMSCs treated group) spinal cord tissue sections showing normal structure the neurons are clearly visible, the outer limits of the grey \& white matters are marked and there were no cystic spaces $(H \& E \times 100$ (a), H\&E $\times 200$ (b)). (c) Photomicrograph of spinal cord tissue section of group IV showing a small amount of tissue hemorrhage $(\mathrm{H})$ a slight gathering of gliocytes (arrow) (H\&E $\times 200)$.

Table 2. Showing quantitative expression of all studied genes.

\begin{tabular}{|c|c|c|c|c|}
\hline Gene symbol & Mean \pm SD & $95 \%$ CI & F test & p value \\
\hline $\begin{array}{l}\text { TGF- } \boldsymbol{\beta} \\
\text { Group I } \\
\text { Group II } \\
\text { Group III } \\
\text { Group IV }\end{array}$ & $\begin{array}{l}0.56 \pm 0.17 \\
1.83 \pm 1.28 \\
0.97 \pm 0.55 \\
0.71 \pm 0.33\end{array}$ & $\begin{array}{c}0.45-0.66 \\
1.02-2.65 \\
0.61-1.32 \\
0.5-0.92\end{array}$ & 7.54 & $0.001^{* *}$ \\
\hline $\begin{array}{c}\text { MMP2 } \\
\text { Group I } \\
\text { Group II } \\
\text { Group III } \\
\text { Group IV }\end{array}$ & $\begin{array}{l}0.69 \pm 0.25 \\
1.51 \pm 0.72 \\
1.14 \pm 0.50 \\
0.99 \pm 0.52\end{array}$ & $\begin{array}{l}0.53-0.85 \\
1.05-1.97 \\
0.82-1.46 \\
0.66-1.32\end{array}$ & 5.01 & $0.004^{* *}$ \\
\hline $\begin{array}{c}\text { MMP9 } \\
\text { Group I } \\
\text { Group II } \\
\text { Group III } \\
\text { Group IV }\end{array}$ & $\begin{array}{l}0.78 \pm 0.25 \\
1.55 \pm 0.60 \\
1.13 \pm 0.45 \\
1.03 \pm 0.36\end{array}$ & $\begin{array}{l}0.62-0.94 \\
1.17-1.94 \\
0.84-1.41 \\
0.80-1.26\end{array}$ & 6.64 & $0.001^{* *}$ \\
\hline
\end{tabular}

$\mathrm{p}$ value highly significant $(\mathrm{p}<0.001)-$ : $\mathrm{p}$ value significant $(\mathrm{p}<0.05)$. 


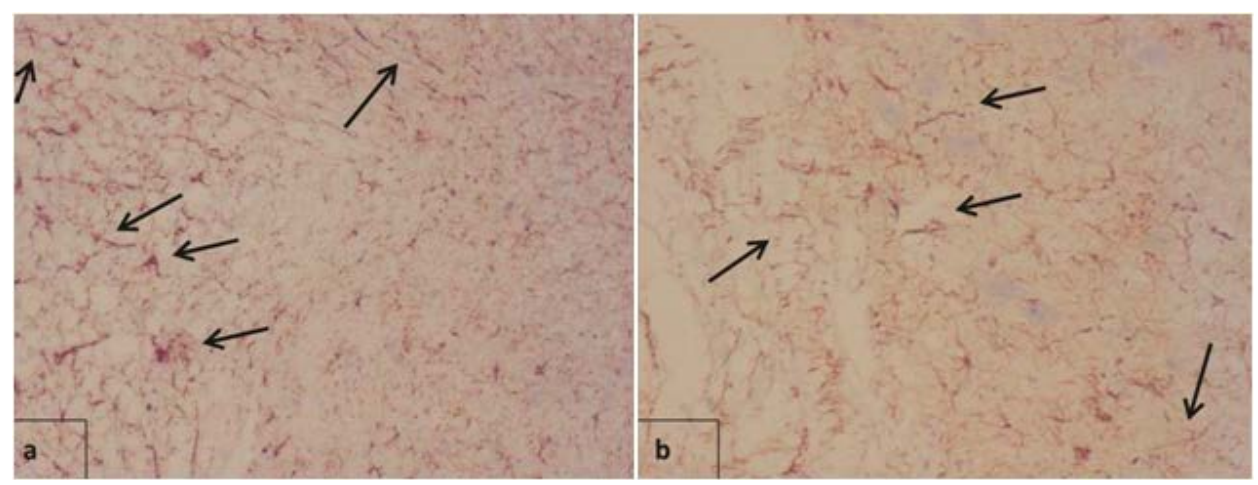

Figure 8. Arrows showing brown immunopositivestaining in the cytoplasm and processes of astrocytes in all regions in white (a) and (b) grey matter (Anti-GFAP ×200).

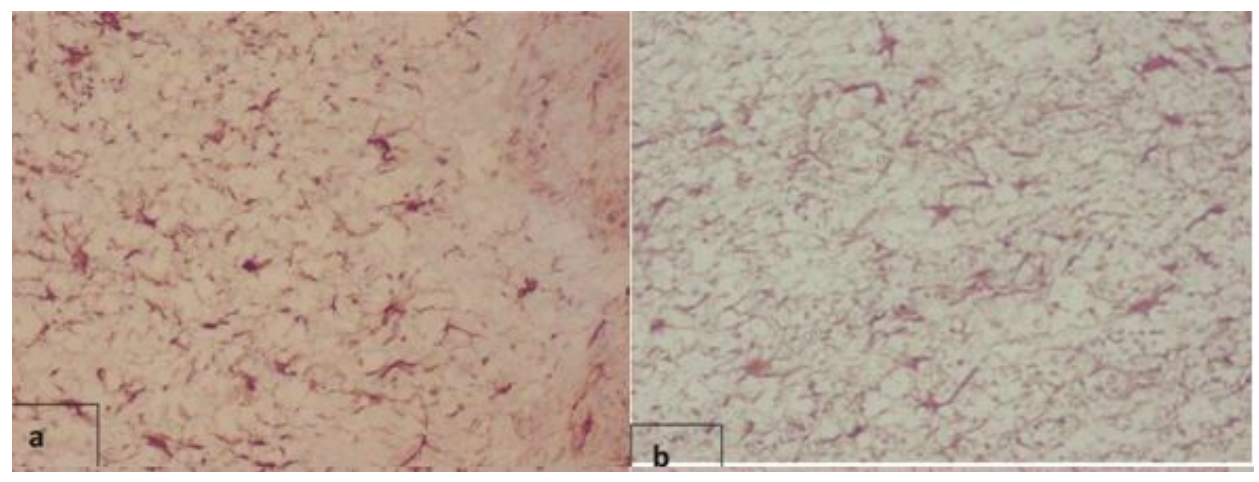

Figure 9. ((a), (b)) Photomicrograph of spinal cord transverse sections group II (untreated group) revealed apparently strong immunopositive staining detected mainly at the sight of lesion (Anti-GFAP × 200).
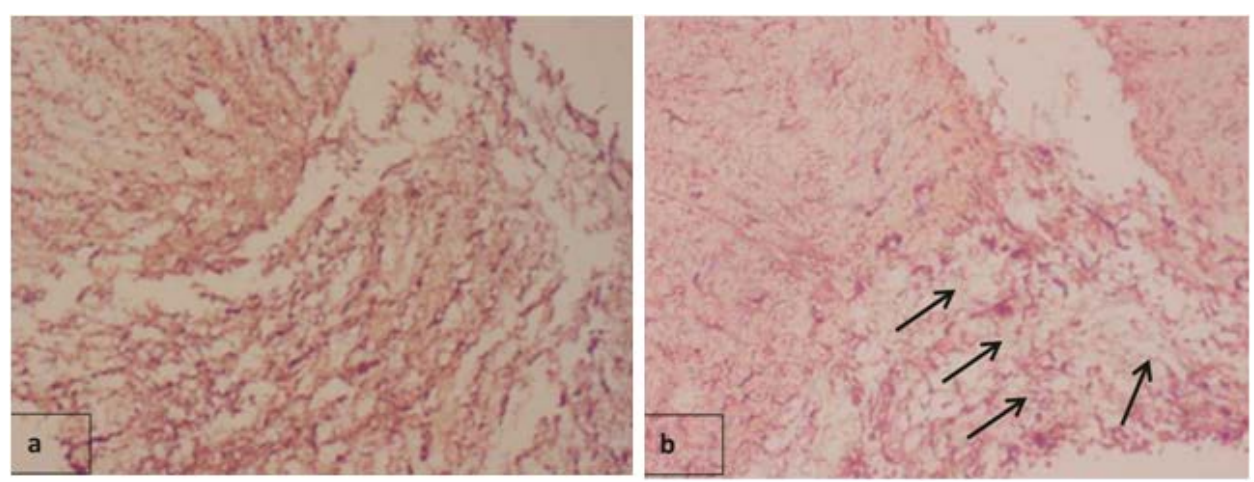

Figure 10. (a) Photomicrograph of spinal cord transverse sections of group III spinal cord sections showed moderate GFAP immunopositive staining in astrocytes (Anti-GFAP $\times 200$ ). (b) Photomicrograph of spinal cord transverse sections of group IV spinal cord sections showed less significant GFAP immunopositive staining (arrows) in astrocytes compared to group III (Anti- GFAP ×200).

Table 3. Showed mean area percent of immunopositive cells in all studied groups.

\begin{tabular}{ccc}
\hline & GFAP stain mean \pm SD & Mylein basic protein stain mean \pm SD \\
\hline Intra-lesional group & $113.2 \pm 26.32$ & $146.74 \pm 4.87$ \\
Intra-venous group & $148.45 \pm 18.3$ & $128.74 \pm 10.18$ \\
Control group & $195.44 \pm 18.23$ & $103.05 \pm 10.7$ \\
F test & 44.68 & 49.26 \\
p value & $0.001^{* *}$ & $0.001^{* *}$ \\
\hline
\end{tabular}

$\mathrm{p}$ value highly significant $(\mathrm{p}<0.001)-$ : $\mathrm{p}$ value significant $(\mathrm{p}<0.05)$. 
Anti-MBP staining established a decrease in density of myelin rings in the degenerating white matter in group II compared to normal control and both treated groups (Figure 11(a), Figure 11(b)). GII overall showed a heterogeneous and shapeless structure, which most likely represented degenerated myelin sheath.

On the other hand number of apparently intact MBP-positive myelin rings visible in GIII shown in (Figure 12(a), Figure 12(b)) with lots of myelin degenerated areas. Group IV showed deep positive MBP staining indicating the good sign of tissue healing to somehow approaching normal spinal cord tissue (Figure 13).

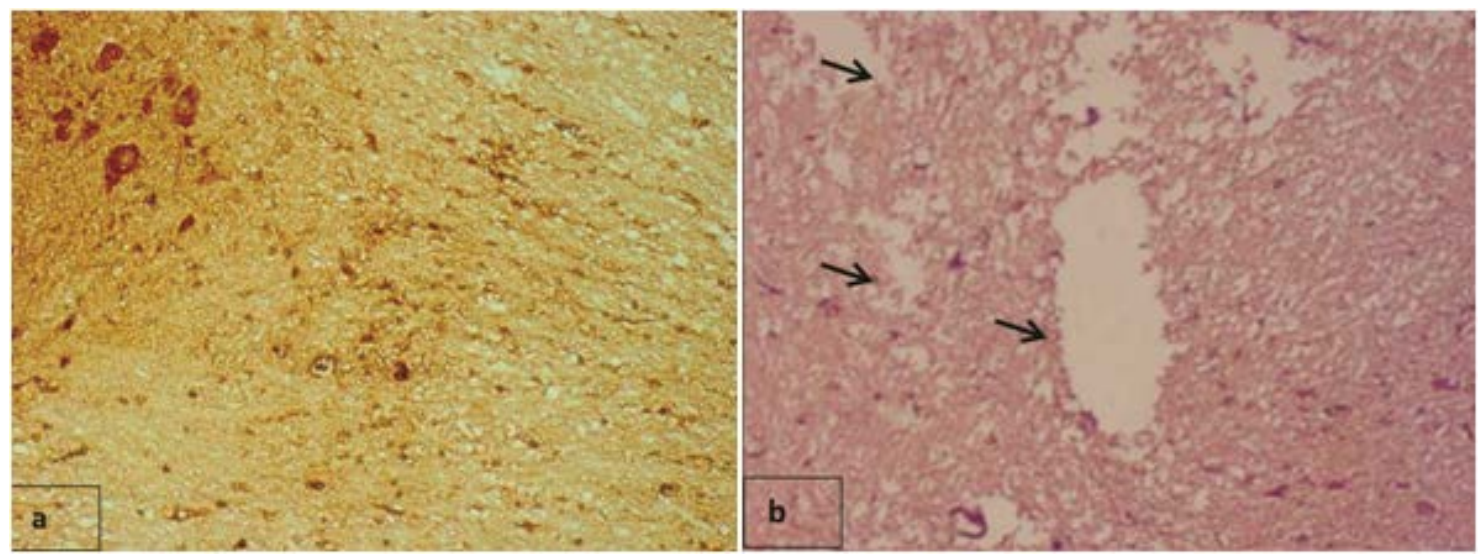

Figure 11. (a) Photomicrograph of spinal cord transverse sections of GI: showing positive myline basic protein staining with normal appearance of white and grey matter. Myline basic protein $(\times 200)$. (b) Photomicrograph of spinal cord transverse sections of GII: showing negative myline basic stain and degeneration in white matter (arrows). Myline basic $(\times 200)$.
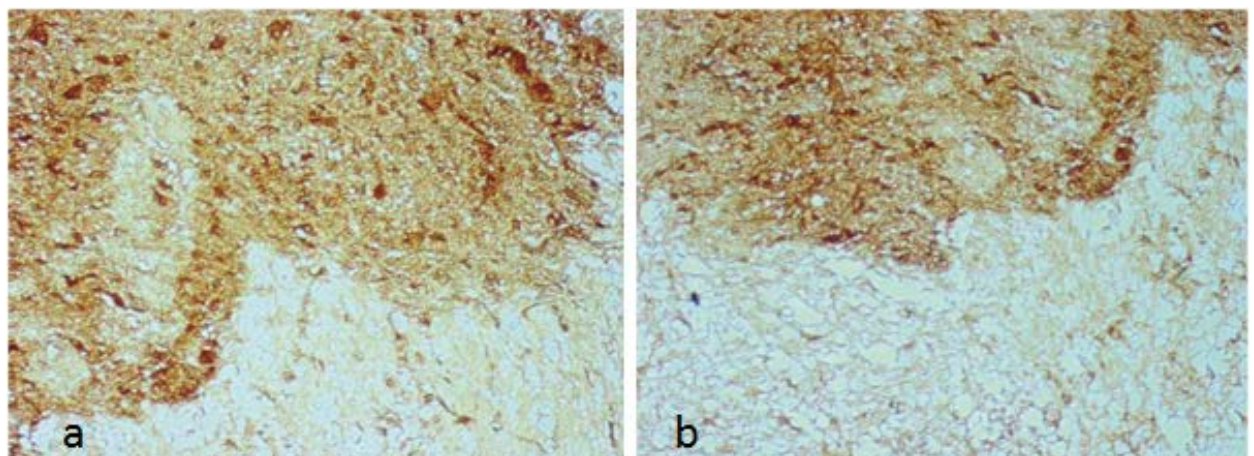

Figure 12. ((a), (b)) Photomicrograph of spinal cord transverse sections GIII: showing moderate reactivity of myelin basic indicating the reformation of myelin sheath. Myelin basic $(\times 200)$.

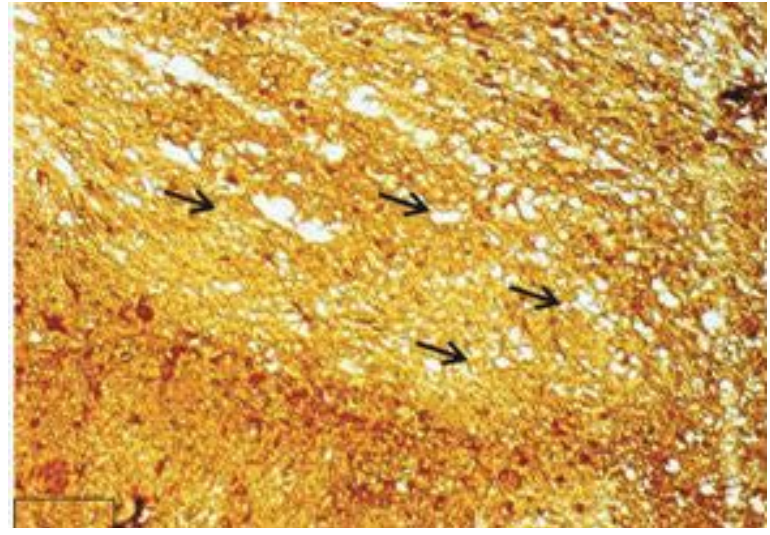

Figure 13. Photomicrograph of spinal cord transverse sections of intra Lesion treated group IV showing strong myelin basic reaction with some Weilerrings (arrows) were observed indicating the reformation of myelin sheath. Myelin basic $(\times 200)$. 


\section{Discussion}

Spinal cord injuries (SCI) result in everlasting incapacities. They persist throughout the person's life, with no chance of recovery. Spinal cord injury is not simply a significance of the initial mechanical destruction of tissue, but also accredited to the evolution of complex secondary events that contribute to early, along with, delayed cell injury. In our study, we aimed at focusing on the role of TGF- $\beta$, MMP-9 and MMP-2 involvement in increasing or decreasing tissue repair after induced SCI. Previous studies showed that TGF- $\beta$ is a major mediator influencing collagen turnover, thus increasing the potential of scar formation in SCI [33].

TGF- $\beta$ has already been known to possess receptors for alpha granules of platelets and macrophages, which in turn increase their accumulation at the sight of injury leading to scar formation [10]. This illustrates its highly expressed potential in untreated group II and its diminished expression in both treated groups III and IV in the present study.

Proteinases like matrix metalloproteinases (MMPs) is a family of extracellular zinc- and calcium-dependent endopeptidases [34], essential for remodeling of the extracellular matrix, tissue morphogenesis, and wound healing. In our study, MMPs are shown to be highly expressed in GII rather than other treated and control groups. However, some investigators perceived that excessive proteolytic activity of MMPs can lead to numerous pathologic conditions, including disruption of the blood-brain barrier [22] [35], and inflammation [36] [37]. MMP-9 reduces collagens, elastin, vitronectin, myelin basic protein and other substrates [38]. This protease is predominantly expressed by inflammatory cells, including macrophages, lymphocytes, and neutrophils, as well as endothelial cells [39] [40]. MMP-9 is expressed in microglia, astrocytes, and hippocampal neurons, and can be induced in astrocytes [41].

We have focused on the role of MMP-9 and MMP-2 because of their beneficial effects in glial scarring [43]. Moreover, the increased migration capacity of white matter astrocytes on laminin is mediated by MMP-9 and MMP-2, thus increasing the reformation of tissue scar [42].

Through our study, we find that in the injured spinal cord untreated GII there is an increase in the level of MMP-9, MMP-2 and GFPA while there is a decrease in the level of MBP. But in GIII and GIV, treated with stem cells, there is a decrease in the level of MMP-9, MMP-2 and GFPA while there is an increase in MBP.

Our findings are concurrent with previous studies were astrogliosis observed in the untreated tissues was attributed primarily to increased migration of astrocytes toward the site of a lesion [43] [44]. Astrocytes-derived from ependymal cells-migrate into the lesion to participate in glial scar formation after spinal cord injury in the adult [45]. Thus, proliferation of migratory astrocytes was involved in astrogliosis; considered to be non-suitable media for tissue regeneration.

The increase in GFAP in GII is due to the alterations in the intermediate filament cytoskeleton which have been occupied in astrocyte motility. Investigators had stated that astrocytes express GFAP as intermediate filament re-expressed in reactive astrocytes, which display abnormal morphology and severely compromised motile behavior [46].

The increase in MBP in our study was attributed to the repairing effect of stem cells which affect how MMPs facilitate the migration of bipotential oligodendrocyte-type 2 astrocyte progenitors on CNS myelin —a strongly inhibitory substrate that can be inactivated by proteolytic degradation mediated by metalloproteases [47]. Hence, decreased Weilerring and reformation of myelin sheath were well observed in group III and group IV in the present study.

Also we found that injection of BM-derived MSC improved the outcome of spinal cord injury as documented clinically by the BBB scoring system for spinal cord injured rats.

Our study results coincided with how other researchers stated that BMSC subpopulations, namely mesenchymal-stem cells (MSCs), accelerate motor recovery when grafted intraspinally in mice with moderate SCI [47]. Additionally, peripheral blood monocytes are required for tissue repair after SCI, likely after being primed into an anti-inflammatory phenotype in the choroid plexus. This hypothesis would then confirm recent data showing that BMSCs have beneficial effects in spinal cord injured mice by modulating the recruitment or the activity of alternatively activated macrophages, therefore, enhancing tissue repair and motor behavior [48].

A previous study conveyed that BMSCs can migrate into the injured part of spinal cord tissue and replace damaged and lost cells, resulting in improved motor function [49]. Another study reported that BMSCs can promote axonal regeneration throughout SCI lesions and improve functional recovery by restoring circuitry motor control [50]. Our results indicate that the immunoreactivity of MBP was stronger in the intralesional GIV compared to the intravenous GIII and GII. These data suggest that BMSCs may provide a supportive matrix for 
intraspinal axonal growth, which is essential for functional recovery from SCI [51] [52].

Further supporting of this finding was the BBB score elevation in GIV compared to that of GIII and GII. It indicated that the presence of BMSCs in the site of the lesion can increase BBB scores and improve functional recovery after SCI [53].

Transplantation of BMSCs has shown great promise in the treatment of SCI [52]. The identification of an optimal method of cell transplantation is essential for the successful treatment of SCI. Local injection [53] or intravenous injection [54] [55] are currently the most common methods of cell transplantation in animal models of SCI. Although direct injection can deliver a large number of BMSCs into the spinal cord tissue, the entry of the needle itself causes further injury. Intravenous injection and lumbar puncture methods are far less invasive, but have a low efficiency, as few transplanted cells ultimately migrate to the SCI lesion [56]. Therefore, increasing the number of cells delivered to the lesion after transplantation is the key to improving functional recovery after SCI [57]. In this study the injected MSCs may create an auspicious environment for functional recovery through modulating the post-SCI inflammatory response and by having neurotrophic activity [58] [59].

BM-MSC transplantation on the animal SCI models have been evidently confirmed by a large number of studies which employedseveral strategies including: pre-neural replacement, neural differentiation, neurotrophic gene transduction, glial cell co-transplantation, and tissue engineering [60]

The above mentioned results were interpreted by the observed movement in the treated rats hind limbs at the end of the experimental duration. Our surveillance was similar to how Song et al. [61] have demonstrated improvement of hind limbs' motor function after allograft of bone MSCs in rats with acute injury to their spinal nerve.

Yin et al. [62] have reported the antiapoptotic effect of MSC transplantation in adult rats after spinal cord ischemia-reperfusion injury. This suggests that MSCs may affect cell regeneration and repair, through control of apoptosis following SCI [63].

Gelatin sponge scaffold used has also been reported to support rat BM-MSC adherence, survival, and proliferation in the rat SCI model. The seeded scaffolds were shown to decrease inflammation, promote angiogenesis, and reduce cavity formation [64] [65].

\section{Conclusions}

BM-MSCs transplantation has a promising role in functional restoration of the spinal cord in rats after chronic spinal cord injury especially with the intralesional route of injection.

Sources of MSCs other than BM have also been known by researchers, such as adipose tissue amniotic fluid, placenta, umbilical cord blood, and in several fetal tissues including liver, lung, and spleen. These sources could be established in SCI

Also combination of anti-matrix metalloprotenases with stem cells will improve the result of MSC transplantation.

\section{References}

[1] Liverman, C.T., Altevogt, B.M., Joy, J.E., Eds. (2005) Spinal Cord Injury: Progress, Promise and Priorities. National Academies Press, Washington DC.

[2] Priebe, M.M., Chiodo, A.E., Scelza, W.M., Kirshblum, S.C., Wuermser, L.A. and Ho, C.H. (2007) Spinal Cord Injury Medicine 6. Economisc and Societal Issues in Spinal Cord Injury. Archives of Physical Medicine and Rehabilitation, 88, S84-S88. http://dx.doi.org/10.1016/j.apmr.2006.12.005

[3] Chhabra, H.S. and Arora, M. (2012) Demographic Profile of Traumatic Spinal Cord Injuries Admitted at Indian Spinal Injuries Centre with Special Emphasis on Mode of Injury: A Retrospective Study. Spinal Cord, 50, 745-754. http://dx.doi.org/10.1038/sc.2012.45

[4] Yip, P.K. and Malaspina, A. (2012) Spinal Cord Trauma and the Molecular Point of No Return. Molecular Neurodegeneration, 7, 6. http://dx.doi.org/10.1186/1750-1326-7-6

[5] Hausmann, O.N. (2003) Post-Traumatic Inflammation Following Spinal Cord Injury. Spinal Cord, 41, 369-378. http://dx.doi.org/10.1038/sj.sc.3101483

[6] Schwab, M.E. and Bartholdi, D. (1996) Degeneration and Regeneration of Axons in the Lesioned Spinal Cord. Physiological Reviews, 76, 319-370

[7] Faulkner, J.R., Herrmann, J.E., Woo, M.J., Tansey, K.E., Doan, N.B. and Sofroniew, M.V. (2004) Reactive Astrocytes 
Protect Tissue and Preserve Function after Spinal Cord Injury. The Journal of Neuroscience, 24, 2143-2155. http://dx.doi.org/10.1523/JNEUROSCI.3547-03.2004

[8] Ashcroft, G.S. (1999) Bidirectional Regulation of Macrophage Function by TGF-Beta. Microbes and Infection, 1, 1275-1282. http://dx.doi.org/10.1016/S1286-4579(99)00257-9

[9] De Groot, C.J., Montagne, L., Barten, A.D., Sminia, P. and Van Der Valk, P. (1999) Expression of Transforming Growth Factor (TGF)-Beta1, -Beta2, and -Beta3 Isoforms and TGF-Beta Type I and Type II Receptors in Multiple Sclerosis Lesions and Human Adult Astrocyte Cultures. Journal of Neuropathology \& Experimental Neurology, 58, 174-187. http://dx.doi.org/10.1097/00005072-199902000-00007

[10] Lagord, C., Berry, M. and Logan, A. (2002) Expression of TGF- $\beta 2$ but Not TGF- $\beta 1$ Correlates with the Deposition of Scar Tissue in the Lesioned Spinal Cord. Molecular and Cellular Neuroscience, 20, 69-82. http://dx.doi.org/10.1006/mcne.2002.1121

[11] Yong, V.W. (2005) Metalloproteinases: Mediators of Pathology and Regeneration in the CNS. Nature Reviews Neuroscience, 6, 931-944. http://dx.doi.org/10.1038/nrn1807

[12] Abdel Aziz, M.T., Atta, H.M., Mahfouz, S., Fouad, H.H., Roshdy, N.K., Ahmed, H.H., Rashed, L.A., Sabry, D., Hassouna, A.A. and Hasan, N.M. (2007) Therapeutic Potential of Bone Marrow-Derived Mesenchymal Stem Cells on Experimental Liver Fibrosis. Clinical Biochemistry, 40, 893-899. http://dx.doi.org/10.1016/j.clinbiochem.2007.04.017

[13] Vu, T.H. and Werb, Z. (1998) Gelatinase B: Structure, Regulation, and Function. Academic Press, San Diego.

[14] Silver, J. and Miller, J.H. (2004) Regeneration beyond the Glial Scar. Nature Reviews Neuroscience, 5, 146-156. http://dx.doi.org/10.1038/nrn1326

[15] McGraw, J., Hiebert, G.W. and Steeves, J.D. (2001) Modulating Astrogliosis after Neurotrauma. Journal of Neuroscience Research, 63, 109-115. http://dx.doi.org/10.1002/1097-4547(20010115)63:2<109::AID-JNR1002>3.0.CO;2-J

[16] Matyash, M., Matyash, V., Nolte, C., Sorrentino, V. and Kettenmann, H. (2002) Requirement of Functional Ryanodine Receptor Type 3 for Astrocyte Migration. FASEB Journal, 16, 84-86.

[17] Etienne-Manneville, S. and Hall, A. (2002) Rho GTPases in Cell Biology. Nature, 420, 629-635. http://dx.doi.org/10.1038/nature01148

[18] Bourguignon, L.Y., Gilad, E., Peyrollier, K., Brightman, A. and Swanson, R.A. (2007) Hyaluronan-CD44 Interaction Stimulates Rac1 Signaling and PKN Gamma Kinase Activation Leading to Cytoskeleton Function and Cell Migration in Astrocytes. Journal of Neurochemistry, 101, 1002-1017. http://dx.doi.org/10.1111/j.1471-4159.2007.04485.X

[19] Menet, V., Prieto, M., Privat, A., Gimenez, Y. and Ribotta, M. (2003) Axonal Plasticity and Functional Recovery after Spinal Cord Injury in Mice Deficient in Both Glial Fibrillary Acidic Protein and Vimentin Genes. Proceedings of the National Academy of Sciences of the United States of America, 100, 8999-9004. http://dx.doi.org/10.1073/pnas.1533187100

[20] Okada, S., Nakamura, M., Katoh, H., Miyao, T., Shimazaki, T., Ishii, K., Yamane, J., Yoshimura, A., Iwamoto, Y., Toyama, Y. and Okano, V. (2006) Conditional Ablation of Stat3 or Socs3 Discloses. Nature Medicine, 12, 829-834. http://dx.doi.org/10.1038/nm1425

[21] Saadoun, S., Papadopoulos, M.C., Watanabe, H., Yan, D., Manley, G.T. and Verkman, A.S. (2005) Involvement of Aquaporin-4 in Astroglial Cell Migration and Glial Scar Formation. Journal of Cell Science, 118, 5691-5698. http://dx.doi.org/10.1242/jcs.02680

[22] Sternlicht, M.D. and Werb, Z. (2001) How Matrix Metalloproteinases Regulate Cell Behavior. Annual Review of Cell and Developmental Biology, 17, 463-516. http://dx.doi.org/10.1146/annurev.cellbio.17.1.463

[23] Yong, V.W. (2005) Metalloproteinases: Mediators of Pathology and Regeneration in the CNS. Nature Reviews Neuroscience, 6, 931-944. http://dx.doi.org/10.1038/nrn1807

[24] Duchossoy, Y., Horvat, J.C. and Stettler, O. (2001) MMP-Related Gelatinase Activity Is Strongly Induced in Scar Tissue of Injured Adult Spinal Cord and Forms Pathways for Ingrowing Neurites. Molecular and Cellular Neuroscience, 17, 945-956. http://dx.doi.org/10.1006/mcne.2001.0986

[25] Wells, J.E., Rice, T.K., Nuttall, R.K., Edwards, D.R., Zekki, H., Rivest, S. and Yong, V.W. (2003) An Adverse Role for Matrix Metalloproteinase 12 after Spinal Cord Injury in Mice. Journal of Neuroscience, 23, 10107-10115.

[26] Hsu, J.Y., McKeon, R., Goussev, S., Werb, Z., Lee, J.U., Trivedi, A. and Noble-Haeusslein, L.J. (2006) Matrix Metalloproteinase-2 Facilitates Wound Healing Events That Promote Functional Recovery after Spinal Cord Injury. The Journal of Neuroscience, 26, 9841-9850. http://dx.doi.org/10.1523/JNEUROSCI.1993-06.2006

[27] Ogier, C., Bernard, A., Chollet, A.M., LED, T., Hanessian, S., Charton, G., Khrestchatisky, M. and Rivera, S. (2006) Matrix Metalloproteinase-2 (MMP-2) Regulates Astrocyte Motility in Connection with the Actin Cytoskeleton and Integrins. Glia, 54, 272-284. http://dx.doi.org/10.1002/glia.20349

[28] Abdel Aziz, M.T., El-Asmar, M.F., Haidara, M., Atta, H.M., Roshdy, N.K., Rashed, L.A., Sabry, D., Youssef, M.A., 
Abdel Aziz, A.T. and Moustafa, M. (2008) Effect of Bone Marrow-Derived Mesenchymal Stem Cells on Cardiovascular Complications in Diabetic Rats. Medical Science Monitor, 14, BR249-BR255.

[29] Erbayraktar, Z., Gokmen, N., Yilmaz, O. and Erbayraktar, S. (2013) Experimental Traumatic Spinal Cord Injury. Methods in Molecular Biology, 982, 103-112. http://dx.doi.org/10.1007/978-1-62703-308-4_6

[30] Gamble, M. (2008) The Hematoxyline and Eosin. In: Bancroft, A.D. and Gamble, M., Eds., Theory \& Practice of Histological Techniques, 6th Edition, Chapter 9, Churchill Livingstone of El Sevier, Philadelphia, 121-135.

[31] Taras, D., Blanc, J.F., Rullier, A., Dugot-Senant, N., Laurendeau, I., Vidaud, M. and Rosenbaum, J. (2007) Pravastatin Reduces Lung Metastasis of Rat Hepatocellular Carcinoma via a Coordinated Decrease of MMP Expression and Activity. Journal of Hepatology, 46, 69-76. http://dx.doi.org/10.1016/j.jhep.2006.06.015

[32] Basso, D.M., Beattie, M.S. and Bresnahan, J.C. (1995) A Sensitive and Reliable Locomotor Rating Scale for Open Field Testing in Rats. Journal of Neurotrauma, 12, 1-21. http://dx.doi.org/10.1089/neu.1995.12.1

[33] Branton, M.H. and Kopp, J.B. (1999) TGF-Beta and Fibrosis. Microbes and Infection, 1, 1349-1365. http://dx.doi.org/10.1016/S1286-4579(99)00250-6

[34] Birkedal-Hansen, H., Moore, W.G., Bodden, M.K., Windsor, L.J., Birkedal-Hansen, B., DeCarlo, A. and Engler, J.A. (1993) Matrix Metalloproteinases: A Review. Critical Reviews in Oral Biology and Medicine, 4, 197-250.

[35] Rosenberg, G.A., Dencoff, J.E., McGuire, P.G., Liotta, L.A. and Stetler-Stevenson, W.G. (1994) Injury-Induced 92Kilodalton Gelatinase and Urokinase Expression in Rat Brain. Laboratory Investigation, 71, 417-422.

[36] Rosenberg, G.A., Estrada, E.Y., Dencoff, J.E. and Stetler-Stevenson, W.G. (1995) Tumor Necrosis Factor-Alpha-Induced Gelatinase B Causes Delayed Opening of the Blood-Brain Barrier: An Expanded Therapeutic Window. Brain Research, 703, 151-155. http://dx.doi.org/10.1016/0006-8993(95)01089-0

[37] Mun-Bryce, S., Rosenberg, G.A. and Gelatinase, B. (1998) Modulates Selective Opening of the Blood-Brain Barrier during Inflammation. American Journal of Physiology, 274, R1203-R1211.

[38] Vu, T.H. and Werb, Z. (1998) Gelatinase B: Structure, Regulation, and Function. Academic Press, San Diego.

[39] Mainardi, C.L., Hibbs, M.S., Hasty, K.A. and Seyer, J.M. (1984) Purification of a Type V Collagen Degrading Metalloproteinase from Rabbit Alveolar Macrophages. Collagen and Related Research, 4, 479-492. http://dx.doi.org/10.1016/S0174-173X(84)80014-X

[40] Hibbs, M.S., Hoidal, J.R. and Kang, A.H. (1987) Expression of a Metalloproteinase That Degrades Native Type V Collagen and Denatured Collagens by Cultured Human Alveolar Macrophages. Journal of Clinical Investigation, 80, 1644-1650. http://dx.doi.org/10.1172/JCI113253

[41] Cuzner, M.L., Gveric, D., Strand, C., Loughlin, A.J., Paemen, L., Opdenakker, G. and Newcombe, J. (1996) The Expression of Tissue-Type Plasminogen Activator, Matrix Metalloproteases and Endogenous Inhibitors in the Central Nervous System in Multiple Sclerosis: Comparison of Stages in Lesion Evolution. Journal of Neuropathology and Experimental Neurology, 55, 1194-1204. http://dx.doi.org/10.1097/00005072-199612000-00002

[42] Takenaga, K. and Kozlova, E.N. (2006) Role of Intracellular S100A4 for Migration of Rat Astrocytes. Glia, 53, 313321. http://dx.doi.org/10.1002/glia.20284

[43] Rhodes, K.E., Moon, L.D. and Fawcett, J.W. (2003) Inhibiting Cell Proliferation during Formation of the Glial Scar: Effects on Axon Regeneration in the CNS. Neuroscience, 120, 41-56. http://dx.doi.org/10.1016/S0306-4522(03)00285-9

[44] Hampton, D.W., Rhodes, K.E., Zhao, C., Franklin, R.J. and Fawcett, J.W. (2004) The Responses of Oligodendrocyte Precursor Cells, Astrocytes and Microglia to a Cortical Stab Injury, in the Brain. Neuroscience, 127, 813-820. http://dx.doi.org/10.1016/j.neuroscience.2004.05.028

[45] Johansson, C.B., Momma, S., Clarke, D.L., Risling, M., Lendahl, U. and Frisen, J. (1999) Identification of a Neural Stem Cell in the Adult Mammalian Central Nervous System. Cell, 96, 25-34. http://dx.doi.org/10.1016/s0092-8674(00)80956-3

[46] Lepekhin, E.A., Eliasson, C., Berthold, C.H., Berezin, V., Bock, E. and Pekny, M. (2001) Intermediate Filaments Regulate Astrocyte Motility. Journal of Neurochemistry, 79, 617-625. http://dx.doi.org/10.1046/j.1471-4159.2001.00595.x

[47] Amberger, V.R., Avellana-Adalid, V., Hensel, T., Baron-van Evercooren, A. and Schwab, M.E. (1997) Oligodendrocyte-Type 2 Astrocyte Progenitors Use a Metalloendoprotease to Spread and Migrate on CNS Myelin. European Journal of Neuroscience, 9, 151-162. http://dx.doi.org/10.1111/j.1460-9568.1997.tb01363.x

[48] Neirinckx, V., Agirman, G., Coste, C., Marquet, A., Dion, V., Rogister, B., Franzen, R. and Wislet, S. (2015) Adult Bone Marrow Mesenchymal and Neural Crest Stem Cells Are Chemoattractive and Accelerate Motor Recovery in a Mouse Model of Spinal Cord Injury. Stem Cell Research \& Therapy, 6, 211. http://dx.doi.org/10.1186/s13287-015-0202-2 
[49] Syková, E., Jendelová, P., Urdzíková, L., Lesný, P. and Hejčl, A. (2006) Bone Marrow Stem Cells and Polymer Hydrogels-Two Strategies for Spinal Cord Injury Repair. Cellular and Molecular Neurobiology, 26, 1111-1127. http://dx.doi.org/10.1007/s10571-006-9007-2

[50] Ankeny, D.P., McTigue, D.M. and Jakeman, L.B. (2004) Bone Marrow Transplants Provide Tissue Protection and Directional Guidance for Axons after Contusive Spinal Cord Injury in Rats. Experimental Neurology, 190, 17-31. http://dx.doi.org/10.1016/j.expneurol.2004.05.045

[51] Houweling, D.A., Lankhorst, A.J., Gispen, W.H., Bär, P.R. and Joosten, E.A. (1998) Collagen Containing Neurotrophin-3 (NT-3) Attracts Regrowing Injured Corticospinal Axons in the Adult Rat Spinal Cord and Promotes Partial Functional Recovery. Experimental Neurology, 153, 49-59. http://dx.doi.org/10.1006/exnr.1998.6867

[52] Himes, B.T., Neuhuber, B., Coleman, C., Kushner, R., Swanger, S.A., Kopen, G.C., Wagner, J., Shumsky, J.S. and Fischer, I. (2006) Recovery of Function Following Grafting of Human Bone Marrow-Derived Stromal Cells into the Injured Spinal Cord. Neurorehabilitation and Neural Repair, 20, 278-296. http://dx.doi.org/10.1177/1545968306286976

[53] Bakshi, A., Hunter, C., Swanger, S., Lepore, A. and Fischer, I. (2004) Minimally Invasive Delivery of Stem Cells for Spinal Cord Injury: Advantages of the Lumbar Puncture Technique. Journal of Neurosurgery—Spine, 1, 330-337. http://dx.doi.org/10.3171/spi.2004.1.3.0330

[54] Fujiwara, Y., Tanaka, N., Ishida, O., Fujimoto, Y., Murakami, T., Kajihara, H., Yasunaga, Y. and Ochi, M. (2004) Intravenously Injected Neural Progenitor Cells of Transgenic Rats Can Migrate to the Injured Spinal Cord and Differentiate into Neurons, Astrocytes and Oligodendrocytes. Neuroscience Letters, 366, 287-291. http://dx.doi.org/10.1016/j.neulet.2004.05.080

[55] Hu, S.L., Lu, P.G., Zhang, L.J., Li, F., Chen, Z., Wu, N., Meng, H., Lin, J.K. and Feng, H. (2012) In Vivo Magnetic Resonance Imaging Tracking of SPIO-Labeled Human Umbilical Cord Mesenchymal Stem Cells. Journal of Cellular Biochemistry, 113, 1005-1012. http://dx.doi.org/10.1002/jcb.23432

[56] Bakshi, A., Barshinger, A.L., Swanger, S.A., Madhvani, V., Shumsky, J.S., Neuhuber, B. and Fischer, I. (2006) Lumbar Puncture Delivery of Bone Marrow Stromal Cells in Spinal Cord Contusion: A Novel Method for Minimally Invasive Cell Transplantation. Journal of Neurotrauma, 23, 55-65. http://dx.doi.org/10.1089/neu.2006.23.55

[57] Paul, C., Samdani, A.F., Betz, R.R., Fischer, I. and Neuhuber, B. (2009) Grafting of Human Bone Marrow Stromal Cells into Spinal Cord Injury: A Comparison of Delivery Methods. Spine (Phila Pa 1976), 34, 328-334. http://dx.doi.org/10.1097/BRS.0b013e31819403ce

[58] Garbossa, D., Fontanella, M., Ducati, A. and Vercelli, A. (2014) Mesenchymal Stem Cell Transplantation Reduces Glial Cyst and Improves Functional Outcome after Spinal Cord Compression. World Neurosurgery, 81, 183-190. http://dx.doi.org/10.1016/j.wneu.2012.08.014

[59] Gu, W., Zhang, F., Xue, Q., Ma, Z., Lu, P. and Yu, B. (2010) Transplantation of Bone Marrow Mesenchymal Stem Cells Reduces Lesion Volume and Induces Axonal Regrowth of Injured Spinal Cord. Neuropathology, 30, 205-217. http://dx.doi.org/10.1111/j.1440-1789.2009.01063.x

[60] Osaka, M., Honmou, O., Murakami, T., Nonaka, T., Houkin, K., Hamada, H., et al. (2010) Intravenous Administration of Mesenchymal Stem Cells Derived from Bone Marrow after Contusive Spinal Cord Injury Improves Functional Outcome. Brain Research, 1343, 226-235. http://dx.doi.org/10.1016/j.brainres.2010.05.011

[61] Song, Q., Xu, R., Zhang, Q., Ma, M. and Zhao, X. (2014) Therapeutic Effect of Transplanting Bone Mesenchymal Stem Cells on the Hind Limbs' Motor Function of Rats with Acute Spinal Cord Injury. Int J Clin Exp Med., 7, 262267.

[62] Yin, F., Guo, L., Meng, C.Y., Liu, Y.J., Lu, R.F., Li, P., et al. (2014) Transplantation of Mesenchymal Stem Cells Exerts Anti-Apoptotic Effects in Adult Rats after Spinal Cord Ischemia-Reperfusion Injury. Brain Research, 1561, 1-10. http://dx.doi.org/10.1016/j.brainres.2014.02.047

[63] Kang, K.N., Kim da, Y., Yoon, S.M., Lee, J.Y., Lee, B.N., Kwon, J.S., et al. (2012) Tissue Engineered Regeneration of Completely Transected Spinal Cord Using Human Mesenchymal Stem Cells. Biomaterials, 33, 4828-4835. http://dx.doi.org/10.1016/j.biomaterials.2012.03.043

[64] Zurita, M., Otero, L., Aguayo, C., Bonilla, C., Ferreira, E., Parajón, A., et al. (2010) Cell Therapy for Spinal Cord Repair: Optimization of Biologic Scaffolds for Survival and Neural Differentiation of Human Bone Marrow Stromal Cells. Cytotherapy, 12, 522-537. http://dx.doi.org/10.3109/14653241003615164

[65] Zeng, X., Zeng, Y.S., Ma, Y.H., Lu, L.Y., Du, B.L., Zhang, W., et al. (2011) Bone Marrow Mesenchymal Stem Cells in a Three-Dimensional Gelatin Sponge Scaffold Attenuate Inflammation, Promote Angiogenesis, and Reduce Cavity Formation in Experimental Spinal Cord Injury. Cell Transplantation, 20, 1881-1899.

http://dx.doi.org/10.3727/096368911X566181 